Brian Mott*

University of Barcelona
UDK $811.111^{\prime} 342.7$

DOI: 10.4312/linguistica.57.1.229-241

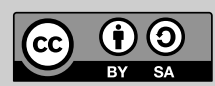

\title{
APPROACHES TO THE SYLLABLE: AN ASSESSMENT
}

\section{INTRODUCTION}

Since the emergence of Prague School linguistics, the syllable has generally been recognized as a fundamental unit in phonological analysis among all the major schools of thought in the field. To Kohler's scepticism (1966) about the universality of the syllable in phonology, for instance, Fudge (1999: 370-371) responds: "I would like to state my firm belief that the syllable is a phonological universal." He also insists on the fact that the syllable must be defined in terms of its relationship to other linguistic constituents: "If we want to state syllable-structure, we must explicitly introduce the element 'syllable' into our linguistic description, and state its relation to other elements of the linguistic hierarchy; it is precisely this which Chomsky and Halle fail to do" (Fudge 1999: 378). For her part, Selkirk (1999: 328) insists that English provides particularly strong evidence of the view that "the syllable is a linguistically significant unit that must have its place in phonological theory." For her it is essentially "[...] a hierarchical unit, an internally structured tree [...]." In support of this same stance, we find Durand (1990: 198-199) affirming that "The syllable needs to be recognized as a unit" and showing that the Polish stress rule, whereby word stress is assigned regularly to the penultimate syllable, can be formulated quite simply by accepting the syllable as a unit without any reference to syllabic composition.

More recently, Goldsmith (2011: 164) reminds us that "The syllable is one of the oldest constructs in the study of language, and most studies of phonology have found a place for the syllable within them." The philologists of the nineteenth century were fully aware of the fact that the outcome of the development of sounds is largely dependent on their phonetic contexts, which might mean their position in the syllable rather than their adjacency to other sounds in the speech chain. The pronunciation of many English words like resist /ri'zist/, absolve /əb'zplv/ and exert/rg'zz:t/, for example, complies with Verner's Law, which, given certain circumstances, predicts voiced fricatives syllableinitially before a stressed vowel instead of unvoiced ones. Similarly, the Second Germanic or High German Consonant Shift, which probably took place cAD 500 and distinguishes High German from the Germanic languages of the Channel coasts and North Sea area, led to an allophonic split among the unvoiced plosives whose outcome depended on their position in the syllable. Thus the unvoiced alveolar plosive / $t /$ was affricated initially ([ts]), but became a fricative ([s]) in coda position, as can be seen by comparing German zehn, aus and Wasser with English ten, out and water.

* mott@ub.edu 
All this, however, is not to say that the concept of the syllable is indispensable in modern phonological theory. For example, Harris (1994: 45) in his description of the phonology of English argues that "[...] for our present purposes, we can manage quite happily without a syllable node." In fact, abstract theories, like government phonology, on the whole, seem to adopt a word-level only (van der Hulst/Ritter 1999: 42).

The aim of this paper is, firstly, to underline the shortcomings of some earlier, purely linear approaches to the syllable, which, view the unit, roughly speaking, either in terms of peaks of prominence derived from the relative sonority of sounds or from the point of view of permissible strings of phonological segments and, secondly, defend Wells syllabic analysis as laid out in the LPD and Wells (1990), while at the same time pointing out the unresolved issues of this approach regarding phonetic correlates of morpheme boundaries, over and against the more abstract, theoretical proposals.

But firstly, evidence for the existence of the syllable will be considered: namely, speaker intuition, on the one hand, and phonological processes that derive from the composition of the syllable, on the other.

\section{EVIDENCE FOR THE EXISTENCE OF THE SYLLABLE}

Speakers are aware of the existence of syllables and are able to count them, or at least count the number of peaks of prominence that are assumed to mark syllables. Ask any native or non-native English speaker how many syllables there are in the words master, penetrate and sympathetic, and the answer will be two, three and four, respectively.

Sometimes, however, there is uncertainty because of the tendency in English to compress unstressed syllables to make words fit as closely as possible the trochaic rhythmic pattern (stressed syllable + unstressed syllable). Thus, med(i)cine, batt(e)ry, dec(o)rative, radio $([\mathrm{i}]>[\mathrm{j}])$, influence $([\mathrm{u}]>[\mathrm{w}])$ may each be pronounced with one syllable less if compressed. Note also that even native speakers of English are often not aware that in words like table and listen, which contain an unstressed liquid or nasal, there are two syllables, and not just one.

A further problem in the identification of syllables is the precise location of the boundaries (see 3.1 below). How should the English words master, rebels, pastry and extra be divided? Is it ma.ster, mas.ter or mast.er; re.bels or reb.els; pa.stry, pas.try or past.ry; ex.tra or ext.ra (or should we split the $<\mathrm{x}>$ into [k] $+[\mathrm{s}]$ ?)? Moreover, can morphological structure be overridden in syllabic division? Wells (see 3.2.1 [1] below), for one, would say no; thus for him the distribution of the vowels and consonants follows the pattern lend.ing and writ.er, not *len.ding and *wri.ter?

Language users are not accustomed to establishing syllable boundaries as they do not normally need to do so, at least as far as spoken language is concerned. If they do need to make a division in a long word in writing, then they will usually take into consideration morphemic structure (e.g. friend + ship, deliver $+i n g$ ) or simply rely on works of reference to answer the problem for them. But syllable structure must be part of a speaker's phonological knowledge because a native speaker of English knows that certain clusters are not well-formed. For instance, there are no English 
words that begin with [lt], though this cluster is possible when final (fault), a fact that is part of native speaker insight. ${ }^{1}$

A second argument that could be considered to testify to the existence of the syllable is the fact that it is the domain of many phonological processes. For example, in French maman [ma'mã] 'mum,' the final [n] nasalizes the preceding vowel, but the intervocalic [m] does not do the same as it is an onset consonant (ma.man), not a coda consonant. There are many processes that affect syllable edges: devoicing of final obstruents in some languages (see footnote 2); aspiration of initial voiceless stops in English; Homorganic Nasal Assimilation in syllable-final position in English (bump, kind, sink), but not necessarily across syllable boundaries (witness moonbeam, gumdrop, gangbang and Sten gun). Glottalling, tapping and rhotacization of English /t/ cannot occur initially, only finally, a weak position which allows suppression of supralaryngeal content and noise release. ${ }^{2}$

Note also how word play underlines the essential reality of the syllable for speakers: a big pan might be fumbled as a pig ban, thus producing a syllable-initial segment exchange, but is unlikely to be pronounced jocularly as a nig bap, with an exchange of consonants occupying different positions in the two syllables.

\section{THEORIES OF THE SYLLABLE}

In this section I shall refer to some traditional interpretations of the syllable that have proved to be inadequate in one way or another and then point out how Wells' proposal remedies some of these shortcomings. The first approach that I examine is one based on the somewhat elusive notion of sonority; the second is a putative universal principle which states that, where possible, consonants are preferably assigned to onsets rather than rhymes.

1 There are analyses that would assign the final consonant of a word like fault and also that of a word ending in a single consonant, like fall, to the onset of a degenerate syllable, i. e., one without an audible nucleus. For a discussion of the advantages of this approach, see Harris (1994: 75). At the same time, note that the coda, while commonly occurring in government style onset-rhyme theories, is not, however, recognized as a constituent in government phonology (van der Hulst/ Ritter 1999: 24).

2 That the rhyme (or more precisely, the coda, if you accept its existence) is a "weak" or nonrobust position is attested by many phenomena apart from those mentioned. For example, in many varieties of Spanish, /s/ is aspirated (or even lost) in this position. Moreover, there tend to be fewer final consonants than onset ones: Spanish has no final plosives. Some languages, like Russian, Polish, Slovene, German and Catalan, neutralize the voice opposition and allow only voiceless [-SON] consonants in this position. Goldsmith (2011: 190) literally refers to the coda as "a position of neutralization," and the onset-coda assymetry is further underlined by Silverman (212: 27-28), who states that neutralization "is almost exclusively found word-finally, and almost never word-initially." Restrictions on consonant types and combinations or on vowel nuclei + consonants are also found. For example, English / $\mathfrak{y} /$ only occurs after short vowels; long vowels are followed by clusters only if they contain an alveolar segment (joint, miles, seemed, but not *laimp, ${ }^{*}$ boonk). 


\subsection{The Sonority Theory}

The Sonority Theory (ST) argues that syllables can be recognized by a peak of prominence flanked by troughs, the sonority of a sound being "its relative loudness compared to other sounds" (Giegerich 1992: 132); thus the sonority first rises, then a peak is reached, and, after that, it falls according to what Selkirk (1984: 116) called a Sonority Sequencing Generalization (SSG) (see also Hogg/McCully 1987: 34). On a seven point scale, the relative sonority values of the sounds of English would be as follows, the most open vowel, /a:/, having the greatest degree of sonority, and a plosive consonant the smallest degree of sonority:

Sonority Level
7
6
5
4
3
2
1

Manner of Articulation
Vowel
Glide
Liquid
Nasal
Fricative
Affricate
Plosive

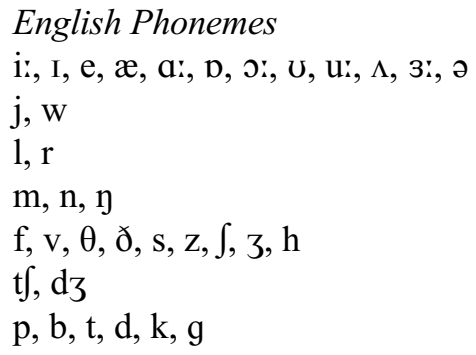

While this theory allows us to establish the number of syllables in a word by identifying the sonority peaks, it fails to determine the syllable boundaries. For example, it is clear that the word terminate has three syllables, as there are three peaks of prominence:

\section{$1 \underline{7} 4 \underline{7} 4 \underline{7} 1$ \\ / $\mathrm{t}$ 3: $\mathrm{m}$ I n eI t /}

However, there is no indication as to which of the following representations reflects the true syllabification of the word:

/ t3:.mi.neit / / t3:m.In.eit / / t3:m.I.neit / / t3:.min.eit /

Another problem with the Sonority Theory, at least as far as English is concerned, is the fact that English allows three-consonant initial clusters beginning with [s] and final consonant clusters ending in [s], as in the words sticks and sprints (but see footnote 3 ). However, [s] is more sonorous than the adjacent plosives, and therefore contravenes the Sonority Sequencing Generalization, which requires the outer segments of syllables to be less sonorous than the inner ones.

Finally, the Sonority Theory cannot inform us about syllable constituency in different languages, i.e. the rules of co-occurrence. For example, both [f] and [s] are voiceless fricatives and therefore have the same sonority value but, whereas initial [sn] is possible in English, [fn] is not; other languages may allow both. Again, the Sonority Theory fails to tell us that *[fljorlnd] is not a legal syllable in English, in which all threeconsonant initial clusters begin with [s] (spread, street, scream, etc.), so *[flj-] is ruled 
out (flew is /flu:/, not*/flju:/ in Present-day English). Likewise, the rhyme *[-orlnd] is illegal since three-consonant codas are supposed to be preceded by short vowels ( $c f$. fifths [fif日s] with five [farv] or fives [farvz]). ${ }^{3}$

Another restriction that a language may impose concerns sonority distance. A language may specify the condition that adjacent segments must stand at a minimal sonority distance from each other (Goldsmith 2011: 177; Steriade 1982: 94). For example, the definition of an optimal syllable according to the SSG predicts that in a two-member onset, the first segment cannot be more sonorous than the second, as in play /ples/, or great/greit/. However, [ml-] and [tl-] do not clash with the SSG and yet they are not possible onset sequences in English. These sequences appear to violate two different language-specific constraints of English. The sequence [ml-] violates a language-specific sonority constraint: within two-member onsets, there must be a minimum sonority distance of 2 points on the sonority scale, so that [fl-] and [gr-], for example, are acceptable. The sequences [tl-] or [fm-], to take another example, are not allowed because the two adjacent members of an onset cannot be homorganic, unless the first one is an [s], as in stay. Neither [tl] nor [fm] conform to this rule: in [tl-] both consonants are alveolar; in [fm-] both consonants are labial. The combinations [tr] and [dr] are admissible in English perhaps because [t] and [d] are alveolar, but [r] is postalveolar, and therefore not homorganic strictly speaking, and they are separated by at least two points on the sonority scale. On the other hand, these sequences tend to be treated monophonematically as affricates, anyway (see 3.2.1 [2]).

The sonority distance requirement for onsets does not seem to apply to codas. This is in accordance with the Dispersion Principle proposed by Clements (1990) and recited by Goldsmith (2011: 177) as: "all things being equal, a language will preferably maximize sonority difference in the onset, but minimize it in the coda."

One final setback to the Sonority Theory that I have only seen mentioned in McCully (2009: 83) is the fact that we also perceive syllable structure when syllables are whispered. To this it might be added that sounds are produced and perceived, in any case, not so much in terms of a sonority scale, but in groups or classes whose membership is defined by the acoustic properties held in common, whether these be related to manner or place of articulation (McCully 2009: 85).

Sonority has been considered in this section on the basis of traditional data, in which obstruents are placed at the bottom of the scale, being assumed to possess negligible sonority, a fact which excludes them from occupying the syllabic nucleus, but there are languages for which syllabic obstruents have been posited, among them the Salishan languages, in which you get long strings of obstruents (see Wells 2016: 109 and Durand 1990: 209). However, this raises basic questions about the nature of the syllable.

3 "Superheavy" onsets and codas are not accepted in all theories. For example, regarding onsets, Harris (1994: 63) says "[...] it is now widely assumed that the imposition of a two-position limit on onsets is universal [...].” Moreover, Harris (1994: 62-63) gives initial and final [s] special status and cites proposals regarding initial [s], not only in English, but also in other languages, like Spanish and Italian. Either the segment is adjoined to some higher node in phonological structure or it is a coda consonant preceded by an unrealized nucleus. 


\subsection{The Maximal Onset Principle}

The Maximal Onset Principle (MOP), referred to by Kennedy (2017: 205) as the "onset preference," assigns as many consonants to the onset of a syllable as permitted by the phonological constraints of the language in question. Thus England must be syllabified as ['rn.glənd], since Modern English disallows [ng] in syllable codas; similarly actress is syllabified as ['æk.tris] because English has no onsets beginning with [ktr]; ['ækt.rIs] is not possible either because [tr] is an affricate and, as such, cannot be split (see 3.1 above).

The main problem with MOP is that it sometimes leaves English short stressed vowels stranded in open syllables and thus requires recourse to an additional rule of ambisyllabicity. If the words winner, honey and bother cannot be divided as ['wI.nə], ['hı.ni] and ['bb.ðə] in accordance with MOP, then ambisyllabicity states that their intervocalic consonants must belong to both syllables. But this looks like a piece of phonological patchwork unless we admit the idea of adjacent syllables being seamless, since these consonantal segments are not articulated as geminates. This is the approach in Local (1990: 355), where ambisyllabicity is regarded as structure-sharing and an integral part of parsing well-formed syllables, rather than a resyllabifying process. This theory postulates ambisyllabicity not just with simplex coda + onset sequences but also in cases like mister, where the cluster [st] would be treated as ambisyllabic, as would the [d] of hardy ['ha:di] despite the preceding heavy syllable (1990: 362).

Further problems arise with the phonological form of certain words like petrol: [tr] is syllable-initial in English, but not syllable-final (though see Wells' division in 3.2.1 [2] below). Given these circumstances, if we apply ambisyllabicity, should the word be divided as pet-trol? Note also the anomalous cases in RP (SSB, GB) where an $[\mathrm{r}]$ has to be spread between two syllables in words like severity [sə.'ver.r..ti]. The problem here is that in the aforementioned variety $[\mathrm{r}]$ is not pronounced in coda position. Compare vision ['vi3.3n], in which [3] would be assigned to an uncustomary initial position as well as a coda.

Strong arguments in favour of ambisyllabicity were put forward by Kahn (1976), whose theory of the syllable is autosegmental, and Durand (1990: 217) admits that "There is [...] evidence that syllables should be allowed to overlap." However, Selkirk (1999: 343) rejects this theory for not allowing the syllable to be viewed as having an internal structure or be represented as part of a higher-order prosodic tree because autosegmental entities are not arranged in a hierarchy with respect to each other: "In an autosegmental analysis, it is impossible to view the syllable as a structural unit of a fully ramified prosodic structure." Selkirk (1999: 345) does, however, lend support to MOP: "In general, when a medial consonant or consonant cluster may be analyzed as either a coda or an onset according to BSC (= basic syllable composition), it is the onset analysis which prevails." In addition to this, Kennedy (2017: 210) makes the important observation that "[...] an internal CC sequence can only be assumed as tautosyllabic if the same sequence is observed word-initially."

Before we leave MOP, it must be remembered that many of the objections to it stem from analyses of English data, but many languages fit the theory perfectly. Languages 
with a rigid CV structure, for example, present no problems of analysis. "MOP is applied through rule ordering: Coda Formation follows Onset Formation and applies only to unsyllabified consonants" (Hayes 2009: 254). Where none exist, there can be no problems of assignment.

\subsubsection{Wells' (2008/1990) Proposal for Syllable Structure}

Wells 2008/1990 includes a proposal for syllabicity which is expounded more fully in Wells 1990: 76-86. In summary, it puts forward the following essential points:

1) Syllable boundaries coincide with word and morpheme boundaries. Thus there is a difference between grey\#tape and great\#ape, and between Tai.pei (T'ai.pei) and type\#A. Similarly, kisses, lending and sunny are syllabified as kiss.es, lend. ing and sunn.y, not *ki.sses, *len.ding and *su.nny.

For morphemes to be recognized as such, they have to be synchronically real to native speakers, although certain words act as if they were morphologically solid: bedr.oom, teasp.oon, mi.stake. In the case of the word mistake, the syllabification is mi.stake because native speakers no longer recognize the word as made up historically of the negative prefix mis- plus the verb take meaning 'consider.' Moreover, the alveolar plosive is unaspirated (see [i] below).

2) Affricates are not split: catch.ing, Rog.er, petr.ol, detr.i.ment, paltr.y, caldr.on. Thus the affricates of catching and Roger, [t $\mathrm{t}]$ and [d3], respectively, cannot be divided as *[t.f] and [d.3].

3) The core of Wells' theory is that, where the previous two conditions can apply without clashing with the phonological constraints of English (e.g. e.nig.ma cannot be *e.ni.gma as [gm] is not a syllable-final cluster in English), the stress (whether primary or secondary) attracts as many consonants as possible: plént.y, ùnd.er.stánd, vúlt.ure /'vıltf.ə/.

4) If a consonant is flanked by two unstressed syllables, it syllabifies to the left: sán.it.y, stím.ul.us.

The proposal in Wells is based on the behaviour of allophones at syllable boundaries. Thus, cases of aspiration, tapping, pre-fortis clipping, r-allophony, plosive epenthesis, $\mathrm{t} / \mathrm{d}$ elision, and (de)voicing occur depending on whether the consonants involved are part of an onset or a coda.

The following examples illustrate each of the linguistic phenomena listed above:

i) Aspiration: that mistake is syllabified as mi.stake. is confirmed by the fact that the [t] is not aspirated and must therefore be preceded by [s] in the same syllable.

ii) Tapping: debt.or, de.ter. As the [t] of the first word can be tapped or glottalized, it must be in the coda of the first syllable; in the second word the aspiration of the $[t]$ confirms its status as syllable-initial.

iii) Pre-fortis clipping: leak.ing v. Lee\#King. If the vowel in the first syllable of leaking is relatively short as compared to that of the name Lee King, then it must be because of pre-fortis clipping, which proves that the $[\mathrm{k}]$ in leaking is in the first syllable. 
iv) r-allophony: your rise $\mathrm{v}$. your eyes. The initial [r] of rise is somewhat rounded in many speakers, whereas the linking [r] of your eyes, if pronounced, does not have this property and is therefore syllable-final.

v) Plosive epenthesis: ten (t)s.ing v. ten sing. Possible plosive epenthesis in tensing proves that the $[\mathrm{n}]+[\mathrm{s}]$ must both be coda consonants. No such epenthesis is possible in ten sing, where the $[\mathrm{n}]$ and $[\mathrm{s}]$ are heterosyllabic.

vi) $[\mathrm{t}] /[\mathrm{d}]$ elision: $[\mathrm{t}]$ and [d] can only be elided in a consonant cluster which is syllable-final. Thus the final [ $\mathrm{t}$ ] of last can be elided in last wit, but the initial [t] of the word twit, as in crass twit, cannot be omitted; likewise, the [d] of old is often elided, for example in the expression old man, but not the [d] in coal dust.

vii) Voicing can also supply some information on syllabification. For example, in a.pply the [1] is voiceless, so the preceding [p], which is voiceless, must be in the same syllable; on the other hand, the [1] in app.li.cat.ion is relatively voiced and cannot therefore have been influenced by the preceding [p]. This shows that the $[\mathrm{p}]$ must belong to the preceding syllable.

\subsubsection{Notes and Comments on Wells' proposal}

The argument that constituency within the syllable is based, at least in part, on distributional or phonotactic considerations is not entirely new (see Selkirk 1999: 329; Pike 1967: 386-387), but the detail provided by Wells (1990: 76-86) in his article on syllabification and allophony is unprecedented.

Regarding each of the four basic conditions for syllabification outlined in 3.2.1 (1-4), I would add the following notes and comments

1) Syllable boundaries coincide with word and morpheme boundaries.

Recognition of the coincidence of morphemes and syllables is, probably rightly, at variance with earlier, more simplistic theories of the syllable, like MOP or the contention expressed by Fudge (1999: 376) that "the /v/ of drive is syllable-final, whereas it is more natural to take the $/ \mathrm{v} /$ of driving as syllable-initial."

2) Affricates are not split.

This makes sense in view of the fact that $[\mathrm{t}]$ ] and [dz] are generally treated as monophonematic, a fact that in metrical phonology can be represented by showing that two melodic units are linked to one skeletal position (Harris 1994: 40). But a problem arises with [tr] and [dr]: LPD divides petrol as /'petr.əl/ since $[\mathrm{tr}]$ is a voiceless affricate and the stressed syllable requires a consonant after the short vowel. Since the affricate cannot be word-final, this calls for a distinction to be made between word internal positions and word edges, though perhaps this is not a bad thing, as these positions do often have different constituency. For example, Spanish has coda [b] internally in submarino, but [b] is rarely word-final (only in foreign words like $c l u b$ ).

3) Conditions 1 and 2 v. sequential constraints on sounds.

This usually works, but note the problems with morpheme boundaries mentioned below. 
It is interesting that, as English speakers pronounce the Spanish name Pepe / 'pepe/ as /'pepi/ or /'pepes/, and not */'perpes/ or */'perpi/, they must therefore be treating the intervocalic $[\mathrm{p}]$ as a coda consonant required by the preceding short stressed vowel, rather than an initial one.

4) If a consonant is flanked by two unstressed syllables, it syllabifies to the left. This syllabic division would appear to be realistic in view of the fact that rhymes are left-headed (for detailed reasoning, see Harris 1994: 149).

Regarding the exemplification relating to allophonic distribution in syllables expounded in 3.2.1 (i-vii), I would add the following notes and comments:

i) Certain short vowels can occur finally in unstressed syllables, so the division of mi.stake shown by the LPD is legal, as would be that of a.spire and a.skance, which also contain unaspirated plosives. Both schwa and the KIT vowel, which we have in the first syllable of mistake, are very common in unstressed open syllables, but other vowels can appear too: Wells (1990: 83) quotes the case of no.stalg.ic, with the Lот vowel in the first syllable, saying that the [s] may be captured by the stressed syllable as there is no morpheme boundary after it.

(ii) Regarding tapping, note that it usually takes place before a weak vowel ([i], [u] and [ə], and sometimes [I] and [u]), so the [t] of latex and Utah, for example, which contain full vowels in the last syllable, is not tapped. However, there is no problem across word boundaries, even if the following vowel is strong, as in put up, get up and quite obviously (Wells 2014: 180).

An interesting case of possible [t]-glottalling can be found in the variable pronunciation of the surname or place name Entwistle (Wells 2014: 36). Those who glottalize the $[t]$ are treating it as syllable-final; those who don't are treating it as syllable-initial. Thus the name is syllabified in different ways by different people: either as Ent.wistle or En.twistle.

Wells (1990: 81) observes that Americans may tap the [t] of quality but not that of politics. This he attributes to the fact that the final syllable of quality has a weak vowel (/I/ or /ii/, according to him), while the vowel of -ics must count as a full vowel sufficient to outrank the preceding weak vowel and capture the [t]. Another way of looking at this would be to recognize -ics as a heavy syllable (and some phonologists would say it bears secondary stress because of this), although this argument will not work with the adjective politic, where the final syllable with only one consonant in the coda is not heavy, and yet this word behaves in the same way as politics as regards syllabification and absence of tapping.

(iii) This seems to provide adequate phonetic evidence to show that that the coda does exist in the face of proposals to the contrary (see footnotes 1 and 3).

Paragraphs iv-vii provide further evidence for the onset-coda dichotomy and underline further the importance of phonetic features in syllable constituency. So it 
would appear that, on the whole, Wells has created a reliable way of assigning consonants to syllables. Nevertheless, it needs to be pointed out that the analysis is hampered slightly by the many cases where morpheme boundaries seem to be overridden. Prefortis clipping in a number of adjectives ending in -ful, like awf.ul, caref.ul, tearf.ul and joyf.ul, as opposed to others, like law.ful, rue.ful, woe.ful and sorr.ow.ful is a case in point. With reference to the former, Wells (1990: 81-82) says that we are not dealing with one of the "synchronic, psychologically real morphemes," and he contrasts awful 'terrible' with awe-ful 'full of awe,' which does not show pre-fortis clipping. It remains to be seen whether all the words with the suffix -ful that undergo pre-fortis clipping are more lexicalized, less transparent to native speakers, and less "psychologically real," to use Wells' terminology, than those that do not.

Even harder to explain than the previous cases are the ones like plent.if.ul, its synonym bount.if.ul, and pow.erf.ul, in which Wells' analysis overrides the morpheme boundary and applies the rule that assigns to the coda a consonant standing between two weak-vowelled syllables (3.2.1 [4]).

To take another example, Wells believes that -ford, unlike some other morphemes, like -ton and -son, does behave phonetically as a separate morpheme, as in Cray.ford $/ \mathrm{kreI.fəd} /$, but it must be remembered that short stressed vowels will require coda consonants, so Staff.ord, for example, will accordingly be divided as /stæf.əd/. As Wells (1990: 82) himself admits, "In general, this whole area of presence / absence of phonetic correlates of morpheme boundaries is still far from fully explored."

\section{CONCLUSION}

This assessment of various, sometimes competing, approaches to an analysis of the syllable has hopefully brought to light some of the strengths and weaknesses of each one, in particular as far as English is concerned. While exclusive recourse to the acoustic properties of this phonological unit fail to cast light on the identification of boundaries, the interpretations that do address this question, like the Maximal Onset Principle and John Wells' proposal, still run into many difficulties, not all of which have been resolved. As far as English is concerned, Wells' approach appears to be the most practical, as is attested by the observations he has made on the distribution of allophones in syllable onsets and codas. This view has the advantage of steering away from the less tangible, more abstract arguments adduced by government phonology, for example. Nevertheless, there is still more work to be done on the relationship between morphology and the division of words into syllables.

I note that in the LPD Wells analyses discredit as dis.cred.it. However, in the American recording of this word I hear no aspiration of the $[\mathrm{k}]$ or devoicing of the [r], which would assume the syllabic division to be di.scred.it. On the other hand, Wells gives discriminate as di.scrim.i.nate, but I believe that I personally devoice the $[\mathrm{r}]$, which would suggest that I assign the [s] to the coda of the first syllable. What are we to make of cases like these? I would go so far as to suggest that syllabic division in theory may clash with syllabic division in reality and maintain that, even though syllabification is predictable in most languages, there is a strong subjective, 
idiosyncratic element in the morphology of some languages, like English, that has hitherto been underrated, especially by largely abstract notions of linguistic analysis that seek to establish hard-and-fast rules for language behaviour. Here the role played by etymology in determining syllabification for individual speakers cannot be ignored. The more transparent a form is to the speaker, the more likely it is that he or she will divide it according to its historical components. Thus I have no qualms about assigning the [s] of dismember to the first syllable, in view of the prior existence of the noun member, but disparage is less clear to me. Even though dis- in this word is historically a separate morpheme, I feel inclined to analyse it as di.sparage. I end with some words relevant to this situation from Zec (2007: 191): "Constraints that make reference to morphological constituencies may affect the place of syllable boundaries [...], while constraints on phonological constituencies higher or lower than the syllable may affect syllable shapes or their weight properties [...]. It is left for future research to establish the range of such interfaces."

\section{References}

CLEMENTS, George N.(1990) "The Role of the Sonority Cycle in Core Syllabification." In: John C. Kingston/Mary E. Beckman (eds), Papers in Laboratory Phonology 1: Between the Grammar and the Physics of Speech. New York: CUP, 283-333.

DURAND, Jacques (1990) Generative and Non-linear Phonology. London: Longman. FUDGE, Eric (1999 [1969]) "Syllables." In: John A. Goldsmith (ed.), Phonological Theory. The Essential Readings. Oxford: Blackwell, 370-391.

GIEGERICH, Heinz J. (1992) English Phonology: An Introduction. Cambridge: CUP. GOLDSMITH, John A. (2011) “The Syllable.” In: John A. Goldsmith/Jason Riggle/ Alan C. L. Yu (eds), The Handbook of Phonological Theory. Oxford: WileyBlackwell, 164-196.

HARRIS, John (1994) English Sound Structure. Oxford: Blackwell.

HAYES, Bruce (2009) Introductory Phonology. Oxford: Wiley-Blackwell.

HOGG, Richard/Chris B. McCULLY (1987) Metrical Phonology: A Coursebook. Cambridge: CUP.

KAHN, Daniel (1976) Syllable-Based Generalizations in English Phonology. Doctoral dissertation. Cambridge, MA: MIT.

KENNEDY, Robert (2017) Phonology: A Coursebook. Cambridge: CUP.

KOHLER, Klaus J. (1966) "Is the Syllable a Phonological Universal?" Journal of Linguistics 2/2: 207-208. http://dx.doi.org/10.1017/S0022226700001493

LOCAL, John (1990) "Syllabification and Rhythm in Non-segmental Phonology." In: Susan Ramsaran (ed.), Studies in the Pronunciation of English. London: Routledge, 350-366.

McCULLY, Chris (2009) The Sound Structure of English: An Introduction. Cambridge: CUP.

PIKE, Kenneth (1967) Language in Relation to a Unified Theory of the Structure of Human Behavior. The Hague: Mouton. 
SELKIRK, Elizabeth (1984) "On the Major Class Features and Syllable Theory." In: Mark Aronoff/Richard T. Oehrle (eds), Language Sound Structure: Studies in Phonology Presented to Morris Halle by His Teacher and Students. Cambridge Mass: MIT Press.

SELKIRK, Elizabeth (1999 [1982]). "The Syllable." In: John A. Goldsmith (ed.), Phonological Theory. The Essential Readings. Oxford: Blackwell, 328-350.

SILVERMAN, Daniel (2012) Neutralization. Cambridge: CUP.

STERIADE, Donca (1982) Greek Prosodies and the Nature of Syllabification. Doctoral dissertation. Cambridge, MA: MIT.

VAN DER HULST, Harry/Nancy A. RITTER (1999) The Syllable: Views and Facts. Berlin: Mouton de Gruyter.

WELLS, J. C. (1990) "Syllabification and Allophony." In: Susan Ramsaran (ed.) Studies in the Pronunciation of English. London: Routledge, 76-86.

WELLS, J. C. (32008). Longman Pronunciation Dictionary. Burnt Mill (Harlow): Pearson/Longman.

WELLS, John C. (2014) Sounds Interesting. Observations on English and General Phonetics. Cambridge: CUP.

WELLS, John C. (2016) Sounds Fascinating. Further Observations on English Phonetics and Phonology. Cambridge: CUP.

ZEC, Draga. 2007. "The Syllable." In: Paul de Lacy (ed.) The Cambridge Handbook of Phonology. Cambridge: CUP.

Abstract

APPROACHES TO THE SYLLABLE: AN ASSESSMENT

In this paper, which looks back at some of the principal ways of viewing the syllable that have been proposed and attempts to assess their relative validity, I firstly refer to evidence for the existence of the syllable and lend support to the argument that the syllable must be part of speakers' phonological knowledge because, not only can they count syllables, but they also know what sound sequences are permissible in them in their native language. Moreover, in this same vein I also recall the fact that the syllable is the domain of many phonological processes (in English, note aspiration and the glottalling, tapping and rhotacization of [t], for example). Finally, I defend the analysis of English syllabification proposed by Wells in the Longman Pronunciation Dictionary over and against other traditional linear models and the more abstract nonlinear models, while recognizing that Wells' hypothesis still leaves unresolved some issues involving the presence/absence of phonetic correlates of morpheme boundaries.

Keywords: the syllable, linear and non-linear phonology, syllabification and allophony, J. C. Wells 


\section{Povzetek \\ ANALIZA PRISTOPOV K ZLOGU}

Članek obravnava nekatera glavna stališča do strukture zloga in jim skuša določiti relativno veljavnost. Najprej se posvetimo obstoju zloga in podpremo trditev, da zlog mora biti del govorčevega fonološkega vedenja, ker le tako zna prešteti zloge in se tudi zaveda, kateri glasovi si lahko sledijo znotraj enega zloga v njegovem maternem jeziku. Spomnimo tudi, da se znotraj zloga dogodijo številni fonološki procesi (v angleščini so to na primer asimilacija, glotalizirani, vibrantni in rotični [t]). Na koncu potrdimo veljavnost Wellsove analize delitve na zloge v angleščini, kot je predstavljena v Longman Pronunciation Dictionary, ki je drugačna od tradicionalnih linearnih modelov in tudi bolj abstraktnih nelinearnih modelov. Pri tem ugotavljamo, da Wellsova hipoteza pušča nerešena nekatera vprašanja, kot sta na primer prisotnost oziroma odsotnost fonetičnih povezav z morfemskimi ločnicami.

Ključne besede: zlog, linearna in nelinearna fonologija, delitev na zloge in alofonija, J. C. Wells 